\title{
The Effectivities of Yoga Gymnastic to Decrease the Level of Postpartum Blues Incidence
}

\author{
Kusumastuti ${ }^{1{ }^{*}}$ Hastin Ika Indriyastuti ${ }^{2}$ Lutfia Uli Na'mah ${ }^{3}$
}

\author{
1,2,3 Midwife Diploma Study Program Muhammadiyah Health Sciences Institute of Gombong \\ ${ }^{*}$ Corresponding author.Email: ncuz.kusuma26@gmail.com
}

\begin{abstract}
Postpartum blues in postpartum mothers are often neglected and ignored so they are not diagnosed and are not cared for properly. If the postpartum blues cannot be recovered, this situation will be developing into postpartum depression and even postpartum psychosis. The rate of postpartum blues incidents in Indonesia is between 50-70\% of postpartum women. $75 \%$ of them occurred in primiparous mothers. One of 10 women who have just delivered birth have a tendency to experience postpartum blues. Efforts that can be done to overcome the postpartum blues is to do light exercise with yoga gymnastic. The purpose of this study was to determine the effectiveness of yoga gymnastic to reduce the incidence of postpartum blues in postpartum mothers. This research used a Quasi Experiment design study "Psssre-Post Test Only Control Group Design" with data analysis using the Wilcoxon Signed Rank Test. A pre-test has been conducted in this research to see the incidence of postpartum blues, then, yoga exercise were given in the treatment group, while education was given in the control group. The Subjects were postpartum mothers of $7^{\text {th }}$ day until $14^{\text {th }}$ day post childbirth, amounting to 22 respondents in each group. The sampling technique used was purposive sampling, whereas the data collection technique used was EPDS questionnaire. The results of the study were obtained clinically in the treatment group after the yoga gymnastic treatment was normal so that a significant result $(\mathrm{p}=<0.002)$ was given after the treatment between the pre-test and post-test groups in the treatment group. In Conclusion, yoga gymnastic have influence in the way that it is reducing the incidence of postpartum blues.
\end{abstract}

\section{Keywords: Postpartum Blues, Yoga Gymnastic, Postpartum mother}

\section{INTRODUCTION}

Postpartum period begins after the placenta is born and ends when the uterus returns to normal as well as before getting pregnant. During this time, the mother will experience a process of physiological and psychological adaptation [1] .

Postpartum blues are senses of sadness that occur immediately after delivery birth with symptoms starting two or three days after delivery and usually disappear within one or two weeks[2]. The incidence rate of postpartum blues according to the World Health Organization (WHO) in 2009 estimated that when giving birth, women who experienced mild depression (postpartum blues) ranged from 10 to 100 per 1000 live births, while moderate or severe postpartum depression ranged from 30 to 200 per 1000 live births [3].

The incidence of postpartum blues in Indonesia has not been widely treated by hospitals. However, the results of the research of at Boseni Mojokerto Hospital identified that of 37 respondents were $59.5 \%$ experiencing postpartum blues [4]. At Dustira Cimahi Hospital found $52.1 \%$ of women had postpartum blues using EPDS (Edinburg Postnatal Depression Scale) [5]. In Indonesia the incidence of postpartum blues is between $50-70 \%$ of women after childbirth. $75 \%$ of them occur in primiparous mothers [6]. One in 10 women who has just given birth has a tendency to postpartum blues This number indicates that the rate of postpartum blues among mothers is still relatively high, this special attention needs to be taken into account [7].

Postpartum blues are caused by a decrease in the level of reproduction of the hormone progesterone that occurs after giving birth. Although these stressors tend to decrease hormone levels, several factors may be predisposition in patients. Efforts that can be made to overcome postpartum blues is by doing light exercise. Mild exercise is proven to improve mood [8].

Yoga is often recommended for postpartum mothers who often experience mood changes or often feel tired. One of the benefits of yoga is that it may prevent the incidence of postpartum blues. Yoga is done for peace of mind besides making the body become fresher after doing yoga.

Based on the results of a preliminary survey in the Independent Practice of Midwives (IPM) in Gombong area, the data were obtained that the number of women giving birth each month was 25 women. Based on the result of interview with postpartum mothers, 7 of 12 of them felt tired, lack of sleep, crying sensation, and sadness (post partum blues) after giving birth. This has become an interest of researchers to conduct yoga gymnastic to reduce the number of postpartum blues incidence. 


\section{METHOD}

This research was a quasi-experimental study, using the design of "Pre-Post Test Only Control Group Design". This design is used by a group of subjects. First, the subjects are measured, then treated for a certain period, then measured for the second time [9]

The population in this study were all postpartum mothers in a total of 44 people consisting of 22 control groups and 22 intervention groups. The sample in this study were mothers who gave birth spontaneously both primiparous /multiparous and were willing to become the respondents. Meanwhile, the exclusion criteria were post partum mothers who had complications during childbirth.

The analysis used was univariate and bivariate with Wilcoxon Signed Rank Test. This research has gone through the ethical clearance test process[10]

\section{RESULT}

Table 1. The Incidence of Postpartum Blues in the Intervention and Control Groups During the Pre-Test and Post-Test.

\begin{tabular}{|l|l|l|}
\hline Variable & $\mathrm{n}$ & $\%$ \\
\hline Postpartum blues (Pre-test) & & \\
\hline Normal & 29 & 65.9 \\
\hline Postpartum blues & 15 & 34.1 \\
\hline Postpartum blues (Post-test) & & \\
\hline Normal & 39 & 88.6 \\
\hline Postpartum blues & 5 & 11.4 \\
\hline
\end{tabular}

Table 1 shows that based on the result of the pre-test, there are 15 respondents $(34,1 \%)$ identified with postpartum blues, while the post-test result shows that there is a decrease in the number of respondents who experience postpartum blues, which is as much as 5 respondents $(11,4 \%)$.

Table 2. The Incidence of Postpartum Blues in the Intervensi and Control Group in the Pre-Test

\begin{tabular}{|l|c|c|c|c|c|}
\hline \multirow{2}{*}{} & \multicolumn{2}{|l|}{ Normal } & \multicolumn{2}{l|}{ Postpartum blues } & $\mathrm{p}$ \\
\cline { 2 - 5 } & $\mathrm{n}$ & $\%$ & $\mathrm{n}$ & $\%$ & \\
\hline Pre-test & & & & & \\
\hline Group Interventions & 12 & 41.4 & 10 & 66.7 & 0.112 \\
\hline Group Control & 17 & 58.6 & 5 & 33.3 & \\
\hline
\end{tabular}

Table 2 shows that based on the pre-test result, there are 10 respondents who got postpartum blues incidence $(66,7 \%)$ in the intervention group, whereas there are 5 respondents $(33,3 \%)$ in the control group who experienced postpartum blues.

Table 3. The Incidence of Postpartum Blues in Postpartum Mothers Before and After Yoga Gymnastic in The Intervention Group

\begin{tabular}{|l|l|l|l|}
\hline Sign & Obs & Sum ranks & p value \\
\hline Positive & 0 & 0 & $<0.002$ \\
\hline Negative & 10 & 175 & \\
\hline Zero & 12 & 78 & \\
\hline & 22 & 253 & \\
\hline
\end{tabular}

Based on the results of the Wilcoxon Signed Rank Test between pre-test and post-test after doing yoga exercise in the intervention group, it can be seen that clinically the treatment group after being given treatment results becomes normal. The results obtained p-value $<0.002$ means that the results are significant (to be normal) after being given yoga treatments between the pre- test and post-test groups in the intervention group. 
Table 4. Pre-Test and Post-Test of the Incidence of Postpartum Blues in The Intervention Group After Yoga

\begin{tabular}{|l|l|l|}
\hline \multirow{2}{*}{$\begin{array}{l}\text { Postpartum blues } \\
\text { (Pre-test) }\end{array}$} & Normal & Postpartum blues \\
\hline Normal & $\mathrm{N}$ & $\mathrm{N}$ \\
\hline Postpartum blues & 12 & - \\
\hline Total & 10 & - \\
\hline
\end{tabular}

Based on table 4 it can be concluded that the incidence of postpartum blues in the treatment group between the pretest and post-test from the previous 10 becomes nonexisten

Table 5. The Incidence of Postpartum Blues in The Postpartum Mothers of Group Control

\begin{tabular}{|l|l|l|l|}
\hline Sign & Obs & Sum ranks & P-Value \\
\hline Positive & 0 & 0 & - \\
\hline Negative & 0 & 0 & \\
\hline Zero & 22 & 253 & \\
\hline
\end{tabular}

Based on the results of the Wilcoxon Signed Rank Test between pre test and post-test after doing yoga exercise, it can be seen that clinically the treatment group after being given treatment results did not change. There is no $\mathrm{P}$ value because in the result of pre- test and post-test there is no change

Table 6. The Incidence of Postpartum Blues in The Pre-Test and Post-Test of Group Control.

\begin{tabular}{|l|l|l|}
\hline \multirow{2}{*}{ Postpartum blues (Pre-test) } & \multicolumn{2}{|c|}{ Postpartum blues (Post- test) } \\
\cline { 2 - 3 } & Normal & Postpartum blues \\
\cline { 2 - 3 } & $\mathrm{N}$ & $\mathrm{N}$ \\
\hline Normal & 17 & 5 \\
\hline Postpartum blues & 0 & 5 \\
\hline Total & 17 & 0 \\
\hline
\end{tabular}

From these tables, it is found that there are no changes between the pre-test and post-test in the control group, namely the incidence of postpartum blues 5 respondents

\section{DISCUSSION}

Psychologically a woman who has just given birth will experience psychological pressure. There are many women who feel excited with the birth of their babies at the first glance, but they may gradually develop mood disorders, feelings of sadness and pressure after giving birth [11].

The results of this study in all respondents both of the control and intervention groups indicate that there were some respondents at the time of the pre-test experiencing postpartum blues by 15 respondents $(34.1 \%)$ while in the post-test results there was a decrease in the number of respondents who experienced postpartum blues by 5 respondents $(11,4 \%)$.

From the intervention group, it is found that the number of postpartum blues between pre-test and posttest decreased from the previous 10 respondents $(66.7 \%)$ experienced post-partum blues to be non-existent or normal $(100 \%)$.
This result shows that the value is significant ( $\mathrm{p}$ value $<0.002$ ), which means that after yoga treatments are given to the intervention group between pre and post-test, the results are normal. Therefore, yoga gymnastic are effective in being able to reduce the incidence of post-partum blues in post-partum mothers.

The results are accordance with the theory, where the significant benefits of yoga gymnastic include reducing depression which is able to create a calming situation, while the meditation technique in yoga can calm a stressful mind. Other yoga techniques are deep breathing techniques to focus the mind so that it makes the mind calmer, this it can overcome the symptoms of depression [12].

Another case happens in the control group, in which those who are identified with normal results remain normal, whereas those who experienced postpartum blues continued to experience it $(11,4 \%)$.

Similarly, the results of research by Irawati et all [4] at the Boseni Mojokerto 
Regional Hospital identified that of 37 respondents there were $59.5 \%$ experiencing postpartum blues. While a study at Dustira Cimahi Hospital, found $52.1 \%$ of mothers experienced postpartum blues using EPDS (Edinburg Postnatal Depression Scale) [5]. While the results on the description of the occurrence of Postpartum Blues in Post-partum Mothers Based on Characteristics at Level IV General Hospital Saringsih, Bandung, showed that almost half had mild postpartum blues $(42.5 \%)$ and almost half (35.0) \%) experience severe postpartum blues [13].

Postpartum blues are moodiness after childbirth, appearing around the second day to two weeks during the postpartum period. This condition arises due to changes in feelings experienced during pregnancy making it difficult to accept the presence of her baby. Other causes include: Hormonal changes, stress, breast milk does not come out, frustrated because the baby cries and does not want to sleep, fatigue during childbirth or illness due to surgery, husband or family do not care and care for the baby alone, there are problems with parents, and feelings of fear lost a baby [14]

The symptoms of postpartum blues that often appear include: very emotional, crying without cause, feeling disheartened, insecure, sensitive, easily offended, feeling lonely, difficult to sleep, even when the baby is sleeping, lost appetite, dislike or afraid to touch the baby, frightening thoughts about the baby [14]

From the treatment, the group found the incidence of postpartum blues in the treatment group between the pre-test and post-test of the previous 10 respondents experienced postpartum blues to no-one experienced postpartum blues after doing yoga gymnastic.

A mother who has just given birth may experience various problems such as substandard breastfeeding, stress or even fatigue from taking care of the baby. Mother can overcome this problem by doing yoga. Postpartum blues after childbirth usually occur when the mother is too worried about the future of her baby. But yoga has breathing techniques that can help to cope with and eliminate stress and depression so that the puerperal mother will feel calmer in caring for and caring for the baby. Therefore, doing yoga for mothers with postpartum blues is very appropriate [8]

Yoga is the union of the soul, body and mind related to health and fitness. Yoga is an activity where a person concentrates all of his minds to control his five senses and his body as a whole, which means to control, regulate, and concentrate, which functions to harmonize our body, soul and mind, in addition, yoga therapy can smoothen the flow of oxygen in the body so that the body can become healthier[12]. Yoga is a holistic system of practice on the mind and body for mental and physical health through strength, breathing gymnastic, deep relaxation and meditation to practice concentration. Yoga has been proven to reduce stress and can improve mood.

In addition, there are other benefits of yoga in psychiatric conditions such as depression and anxiety respiratory disorders such as asthma, cardiovascular disorders such as hypertension, endocrine disorders such as diabetes, and various nerve and muscle conditions [15].

Yoga also has benefits for mental and physical health, namely increasing body awareness, reducing chronic stress, listening to the body by relieving muscle tension, calming the mind and body both prevention and therapy, sharpening concentration [16].

Similarly, in the control group where there were no changes in the results that remained normal, there were no respondents who experienced postpartum blues. That is the significant benefit of yoga gymnastic, by which it may reduce depression because it is creating a calm situation. Some styles of yoga use special meditation techniques to make the often-stressed mind calm. Other styles of yoga also use deep breathing techniques to focus the mind so it makes mind becomes calmer and it will overcome the symptoms of depression [8].

\section{CONCLUSION}

After analysis and discussion, the following conclusion can be drawn:

1. There were 15 respondents $(34,1 \%)$ experiencing postpartum incidence during pre-test. The number decreases into 5 respondents $(11,4 \%)$ after posttest.

2. Clinically the intervention group after being given yoga gymnastic results are normal. The results obtained p-value $<0.002$ statistically means that the results are significant (normal) after treatment was given between the pre-test and post-test groups in the treatment group.

3. Yoga gymnastic are effective for reducing the incidence of postpartum blues in postpartum mothers.

\section{ACKNOWLEDGMENT}

Thank you to Muhammadiyah Health Sciences institute of Gombong, which has provided moral and materials support, as well as the Independent Practice of Midwives (IPM) in Kebumen Central Java Indonesia who have collaborated to be part of this research.

\section{REFERENCES}

[1] A. Sulistyawati and E. Nugraheny, "Buku Ajar Asuhan Kebidanan Pada Ibu Nifas. Jogjakarta: CV Andi Offset; 2009.," Jakarta Salemba Med., 2009. 
[2] M. Bobak, J. Dejmek, I. Solansky, and R. J. Sram, "Unfavourable birth outcomes of the Roma women in the Czech Republic and the potential explanations: A population-based study," BMC Public Health, 2005, doi: 10.1186/1471-2458-5106.

[3] V. L.M. et al., "Post partum depression: Improving education and screening in the pediatric primary care setting," Pediatrics, 2018.

[4] D. dan Y. Irawati, . "Pengaruh Faktor Psikososial dan Cara Persalinan Terhadap Terjadinya Postpartumblues pada Ibu Nifas," Hosp. Majapahit, vol. 6, [Online]. Available: http://www.politekkesmajapahit.ac.id.

[5] Kirana, "Hubungan Tingkat Kecemasan Postpartum dengan Kejadian Postpartum Blues di RS Dustira Cimahi.," J. Ilmu Keperawatan, vol. III No. 1, 2015.

[6] I. A. Anggarini, M. Hakimi, and A. Hidayat, "Pengaruh Senam Nifas Terhadap Perubahan Maternal Depressive Symptoms Di Rumah Sakit Ibu Dan Anak (Rsia) Sakina Idaman Kabupaten Sleman," Masker Med., 2018.

[7] M. Watanabe et al., "Maternity blues as predictor of postpartum depression: A prospective cohort study among Japanese women," J. Psychosom. Obstet. Gynecol., 2008, doi: 10.1080/01674820801990577.

[8] Yi-Lo, "Exects of Postpartum Exercise Program on Fatigue and Depression During Do Yoga Therapy period.," J. Nurs. Res., vol. 16, pp. 177-183., 2008.

[9] Saryono, Metodologi Penelitian Kesehatan. Yogjakarta: Mitra Cendekia Press., 2008.

[10] Sumadi Suryabrata, Metodelogi Penelitian . Jakarta: PT. Raja Grafindo Persada, 2013.

[11] Hasni, "Hubungan antara Citra Tubuh saat Hamil dan Kestabilan Emoosi dengan Postpartum Blues di Puskesmas Grogol Sukoharjo.," Univ. Sebel. Maret, 2012.

[12] Redha Hajir, Easy Yoga - Sehat dan Fit dengan Yoga Praktis. Jakarta: Penerbit Bukune, 2010.

[13] Lisna Anisa Fitriana, "Gambaran Kejadian Postpartum Blues Pada Ibu Nifas Berdasarkan Karakteristik Di RSU Tingkat IV Sariningsih Bandung.," Fak. Pendidik. Olahraga Dan Kesehat. Univ. Pendidik. Indones., 2015.

[14] R. Astutik, Buku Ajar Asuhan Kebidanan dan Menyusui. Jakarta: CV Trans Info Media, 2015.

[15] Noggle at. al, "Benefits of Yoga for psychosocial well-being in a US high school curriculum: A preliminary randomized controlled trial," J. Dev. Behav. Pediatr., vol. 33(3), pp. 193-201, 2012, doi: 10.1097.

[16] Sharma L, "Benefits of Yoga in Sports- A Study," Int. J. Phys. Educ. Sport Heal., vol. 1, pp. 30-32., 2015. 